\title{
Ultrasound Imaging of Abdominal Wall Endometriosis: A Pictorial Review
}

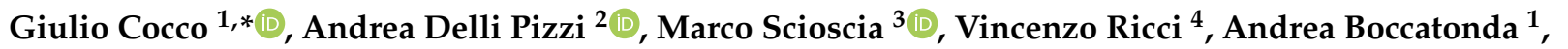 \\ Matteo Candeloro ${ }^{5}{ }^{(0,}$, Marco Tana ${ }^{1}$, Giuseppe Balconi ${ }^{6}$, Marcello Romano ${ }^{7}$ and Cosima Schiavone ${ }^{1}$
}

1 Unit of Ultrasound in Internal Medicine, Department of Medicine and Science of Aging, "G. d'Annunzio" University, 66100 Chieti, Italy; andrea.boccatonda@gmail.com (A.B.); marco_tana@yahoo.it (M.T.); cosima.schiavone@gmail.com (C.S.)

2 Department of Neurosciences, Imaging and Clinical Sciences, “G. d'Annunzio” University, 66100 Chieti, Italy; andrea.dellipizzi@unich.it

3 Unit of Gynecology Surgery, Mater Dei Hospital, 70125 Bari, Italy; marcoscioscia@gmail.com

4 Physical and Rehabilitation Medicine Unit, "Luigi Sacco" University Hospital, A.S.S.T. Fatebenefratelli-Sacco, 20157 Milan, Italy; vincenzo.ricci58@gmail.com

5 Department of Innovative Technologies in Medicine and Dentistry, University "G d'Annunzio", 66100 Chieti, Italy; mat.candeloro@gmail.com

6 Unità Operativa di Radiologia Diagnostica, Ospedale San Raffaele sede di Turro, 20127 Milan, Italy; gbalcon@tin.it

7 Geriatrics Department, Garibaldi Hospital, 95123 Catania, Italy; marcelloromano@tin.it

* Correspondence: cocco.giulio@gmail.com

check for updates

Citation: Cocco, G.; Delli Pizzi, A.; Scioscia, M.; Ricci, V.; Boccatonda, A.; Candeloro, M.; Tana, M.; Balconi, G.; Romano, M.; Schiavone, C. Ultrasound Imaging of Abdominal Wall Endometriosis: A Pictorial

Review. Diagnostics 2021, 11, 609. https: / / doi.org/10.3390/ diagnostics11040609

Received: 24 February 2021

Accepted: 24 March 2021

Published: 29 March 2021

Publisher's Note: MDPI stays neutral with regard to jurisdictional claims in published maps and institutional affiliations.

Copyright: (C) 2021 by the authors. Licensee MDPI, Basel, Switzerland. This article is an open access article distributed under the terms and conditions of the Creative Commons Attribution (CC BY) license (https:// creativecommons.org/licenses/by/ $4.0 /)$.

\begin{abstract}
Endometriosis is a debilitating disease characterized by endometrial glands and stroma outside the endometrial cavity. Abdominal wall endometriosis (AWE) indicates the presence of ectopic endometrium between the peritoneum and the skin, including subcutaneous adipose tissue and muscle layers, often following obstetric and gynecological surgical procedures. AWE is a not infrequent gynecological surgical complication, due to the increasing number of cesarean sections worldwide. In this pictorial review, we discuss the importance of medical history and physical examination, including the main ultrasound features in the diagnosis of AWE.
\end{abstract}

Keywords: abdominal wall endometriosis; ultrasound; cesarean scar; gynecological surgical scar

\section{Introduction}

Endometriosis is a debilitating disease characterized by the presence of endometrial glands and stroma outside the endometrial cavity. It is estimated to affect approximately $7-10 \%$ of women, with clinically relevant symptoms affecting approximately $3 \%$ of women of fertile age [1].

The ectopic tissue is responsive to ovarian hormonal stimulation and proliferates when stimulated by cyclic estrogens, thus appearing to "menstruate" [2]. This disease represents a public health problem, with a major effect on the quality of life of women, as well as having an economic burden [3].

In light of the considerable progress with diagnostic imaging (ultrasound and MRI), exploratory laparoscopy should no longer be used to diagnose endometriotic lesions [4]. Instead, the diagnosis of endometriosis should be based on a structured process involving a combination of patient interviews, clinical examination, and imaging [5,6]. This disorder affects women of reproductive age and generally occurs in pelvic sites, such as the ovaries, bowel, or pelvic peritoneum [7].

Extra-pelvic foci of ectopic endometrial tissue have been described in almost all organs and tissues of the body [8]. Medical history, together with a gynecological examination, has a combined sensitivity of around $80 \%$ for diagnosing endometriosis [9].

Abdominal wall endometriosis (AWE) indicates the presence of ectopic endometrium between the peritoneum and the skin, including subcutaneous adipose tissue and muscle 
layers [10]. Currently, the incidence of AWE following obstetric and gynecological procedures is higher due to the increasing number of caesarian sections worldwide [11]. In detail, the incidence of AWE is about $3.5 \%$ in patients who undergo gynecological surgery and is about $0.8 \%$ in all women with a previous cesarean section [12,13]. Imaging represents a mainstay of the diagnosis and follow-up of abdomino-pelvic diseases [14-16]. In this pictorial review, the authors provide a practical overview on abdominal ultrasound imaging of wall endometriosis, considering the cutaneous, umbilical, subcutaneous, intramuscular, and groin (inguinal canal) locations.

\section{Cutaneous Endometriosis}

Cutaneous endometriosis (CE) is known as the presence of endometrial tissues involving the skin. This condition is estimated to occur at approximately less than $1 \%$ of ectopic sites [17]. Generally, CE occurs secondarily to abdominal surgery, but can be primary, without any previous operations. Physical examination can reveal a palpable, tender, cutaneous mass on abdominal incision, sometimes with multiple tiny red orifices protruding from the skin. In addition to cyclical pain, the patient can show a brownish discharge from the lesion during menstruation. $\mathrm{CE}$ is often confused with other dermatological conditions (e.g., hypertrophic scar or keloid or infection of the scar), thus making the differential diagnosis difficult. [18].

\section{Umbilical Endometriosis}

Umbilical endometriosis is a rare condition that accounts for only $0.5-1 \%$ of endometrial ectopy [19]. Umbilical endometriosis comprises 30-40\% of all CE cases [20], and usually develops in a previous surgical scar (laparoscopic surgery or CS). In rare cases it can be primary [21]. The first case of umbilical endometriosis was credited in 1886 to Villar, hence the term "Villar node" [22]. Umbilical endometriosis can sometimes be associated with an umbilical hernia [19]. That condition is particularly facilitated by previous pregnancies and surgery. When people have undergone abdominal surgery (laparotomy or laparoscopic surgery), the incisions into the abdominal cavity may not heal well and a hernia can form in this site [19-21]. Umbilical endometriosis usually occurs in patients of reproductive age, is typically solitary, and presents a palpable nodule at the umbilicus. Moreover, it may coexist with pelvic endometriosis. The nodule can be covered by a reddish brown discharge, with swelling, pain, discharge, or cyclical bleeding from the umbilicus. These lesions are variable in size, are usually bluish-black in color and become painful, larger, and bleed around the time of menses [23,24]. Ultrasound shows a well-defined hypoechoic mass on the skin of the abdominal scar or at the umbilicus. Intralesional vascular spots can be detected on color Doppler examinations. Moreover, an umbilical endometriosis hernia, through a defect in the linea alba, can be observed (Figure 1a-d). 

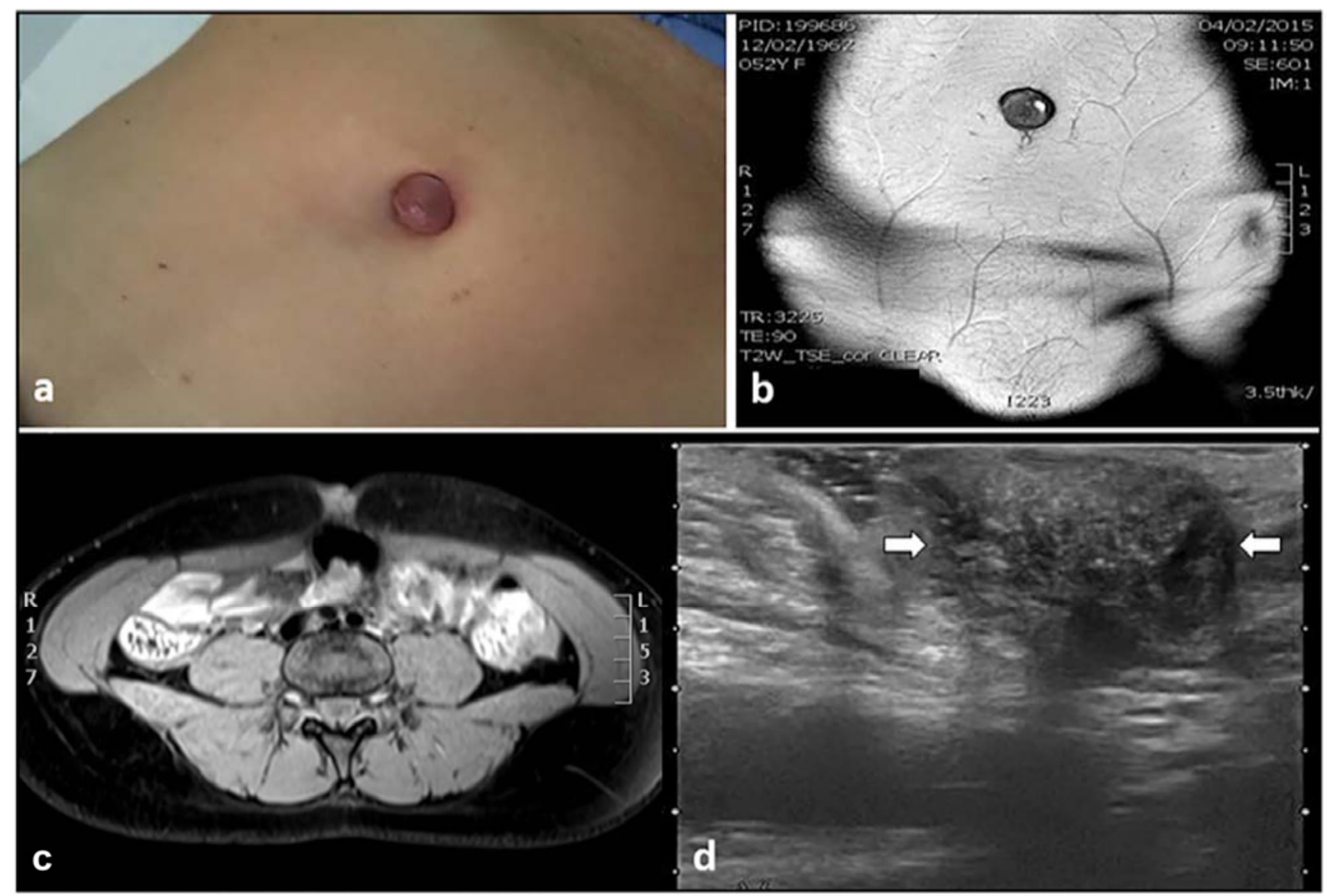

Figure 1. Umbilical mass, identified during physical examination (a), studied with MRI (b,c), and ultrasound imaging (d). White arrows in $\mathrm{d}$ revealed a hypoechoic hernial sac and intralesional hyperechoic spots, representing an umbilical hernia with endometriosis foci.

\section{Subcutaneous Endometriosis}

Subcutaneous endometriosis is the most frequent form occurring in the abdominal wall. Patients usually complain of focal tenderness in the right or left inguinal area, dyspareunia, with local swelling and a palpable mass [10,25-27]. If the woman is overweight, the mass may not be appreciated on palpation [27]. Generally, the past medical history is suggestive of cesarean or gynecological section. The abdominal pain can occur some years after the last cesarean section $[10,13,25,27]$. The nodule is located beneath the cesarean scar and superficially to the rectus abdominis muscle fascia (Figure 2a-c). Sonographic examination of the abdominal wall can reveal a heterogeneous hypoechoic mass with indistinct edges in the right or left inguinal region and at the level of the subcutaneous tissue. Color Doppler examination can detect the presence of intralesional vascular spots, and elastosonography can reveal a harder pattern compared to the surrounding tissues (Figure 3a-c) [27]. 


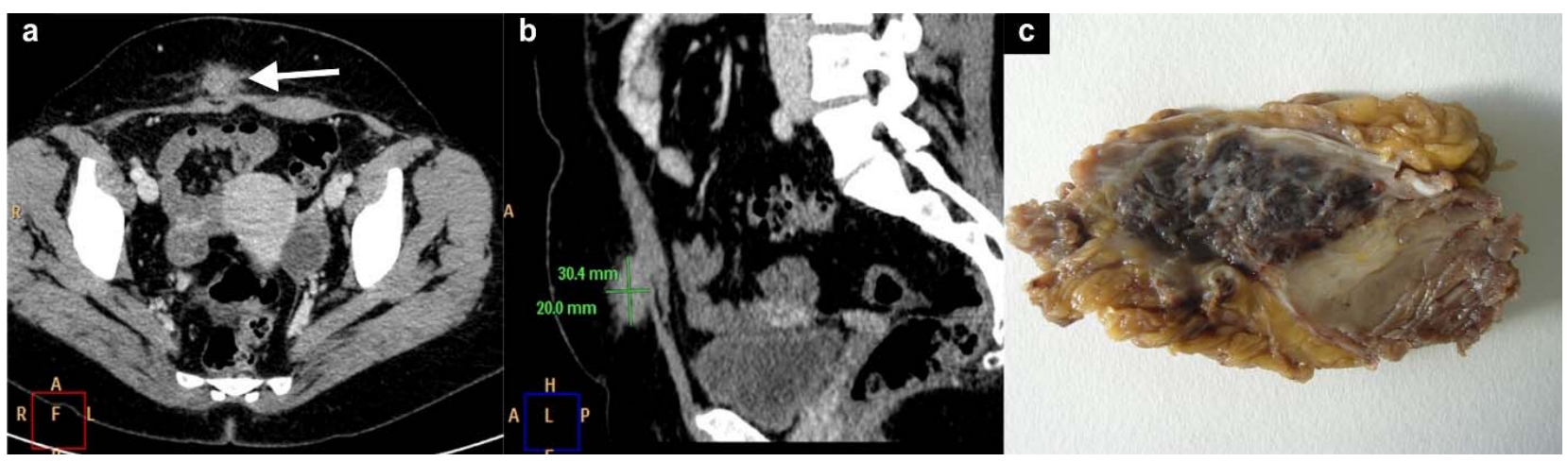

Figure 2. Axial (a) and Sagittal (b) CT images of a histologically proved (c) of subcutaneous endometriosis. A $30 \times 20 \mathrm{~mm}^{2}$ endometriotic nodule (white arrow in a) was detected superficially and in contiguity with the right rectal muscle.
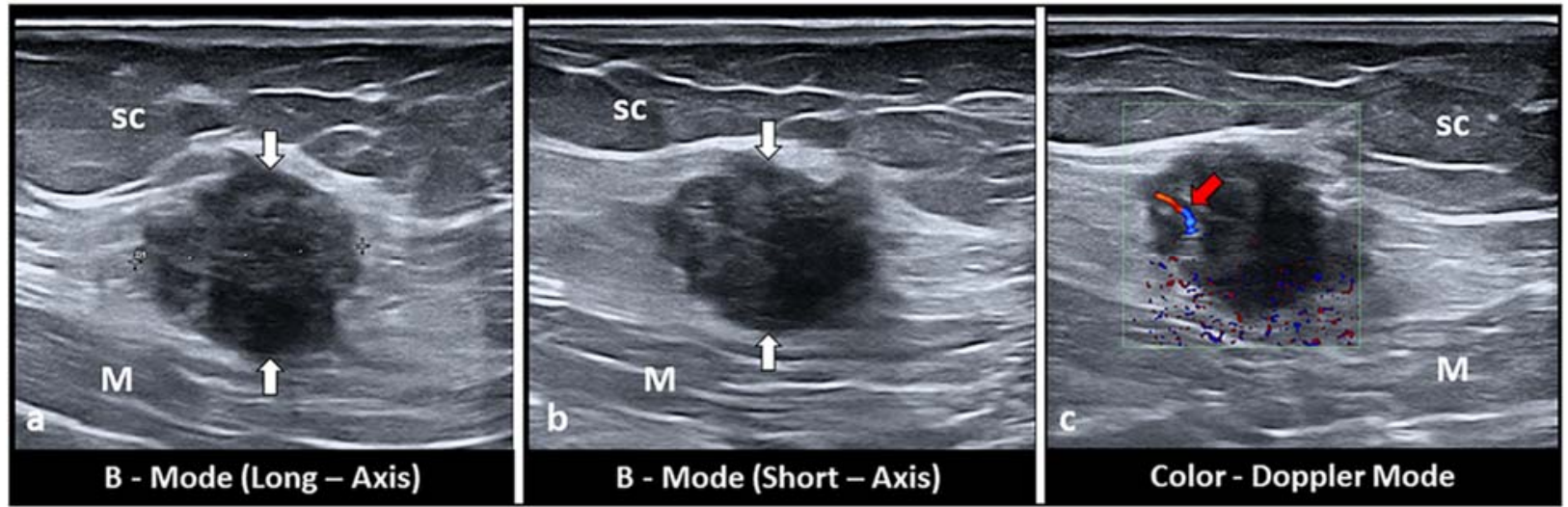

Figure 3. Long-axis (a) and short-axis (b) sonograms show a hypoechoic, nodular mass (white arrows), located between the subcutaneous tissue (sc) and the muscular plane (M) of the abdominal wall. Of note, fine intralesional, vascular spots (red arrow) are depicted on the color Doppler (c).

\section{Intramuscular Endometriosis}

Intramuscular endometriosis lesions are often not palpable because the muscle tissue is deeper than the subcutaneous tissue [27]. Generally, the patient's past medical history includes cesarean section or gynecological surgery. The abdominal pain, generally on the right or left side of the Pfannenstiel scar, can occur some years after the last cesarean section, with the pain being intermittent and strongly correlated with menstrual cycle [10,13,25-27]. Ultrasound examination can show a hypoechoic mass located inside the rectus abdominis muscle with indistinct edges, sometime with intralesional fluid collections. Color Doppler imaging may reveal the presence of intralesional vascular spots. Elastosonography usually shows a harder pattern compared to the surrounding tissues (Figure $4 \mathrm{a}-\mathrm{c}$ ). 

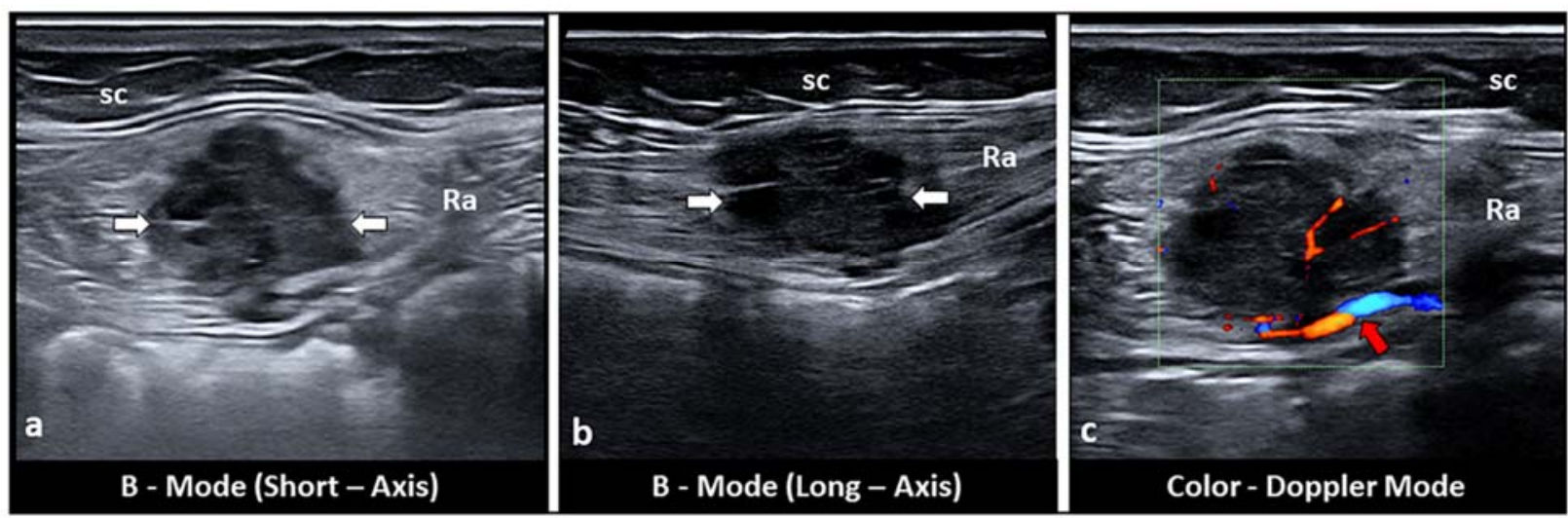

Figure 4. Short-axis (a) and long-axis (b) sonograms show a hypoechoic, nodular mass (white arrows), located inside the rectus abdominis ( $\mathrm{Ra}$ ) muscle. Of note, fine intralesional, vascular spots (red arrow) are depicted on the color Doppler mode (c). sc: subcutaneous tissue.

\section{Inguinal Canal Endometriosis}

Inguinal hernia endometriosis is a possible cause of inguinal masses in females [28]. A hydrocele of the canal of Nuck in females is analogous to the encysted hydrocele of the spermatic cord in men $[29,30]$. Endometriosis localized to the canal of Nuck is very rare and difficult to appreciate clinically. The incidence of endometriosis in the extraperitoneal portion of the round ligament is $0.42 \%$ [31]. The patient often has a history of gynecological surgery or cesarean section, but this condition can also be primary. Generally, the pain pattern can be intermittent and strongly correlated with menstrual cycle. Ultrasound examination may show a hypoechoic solid nodule in the inguinal canal (Figure 5), but may contain a mixed solid and cystic component. In a recent review, Prodromidou et al. analyzed and evaluated the clinical presentation, diagnostic features, and management of Nuck's endometriosis in 36 patients from 20 studies. The authors reported a median age of 36 years and a prevalence of right-side lesions [32].
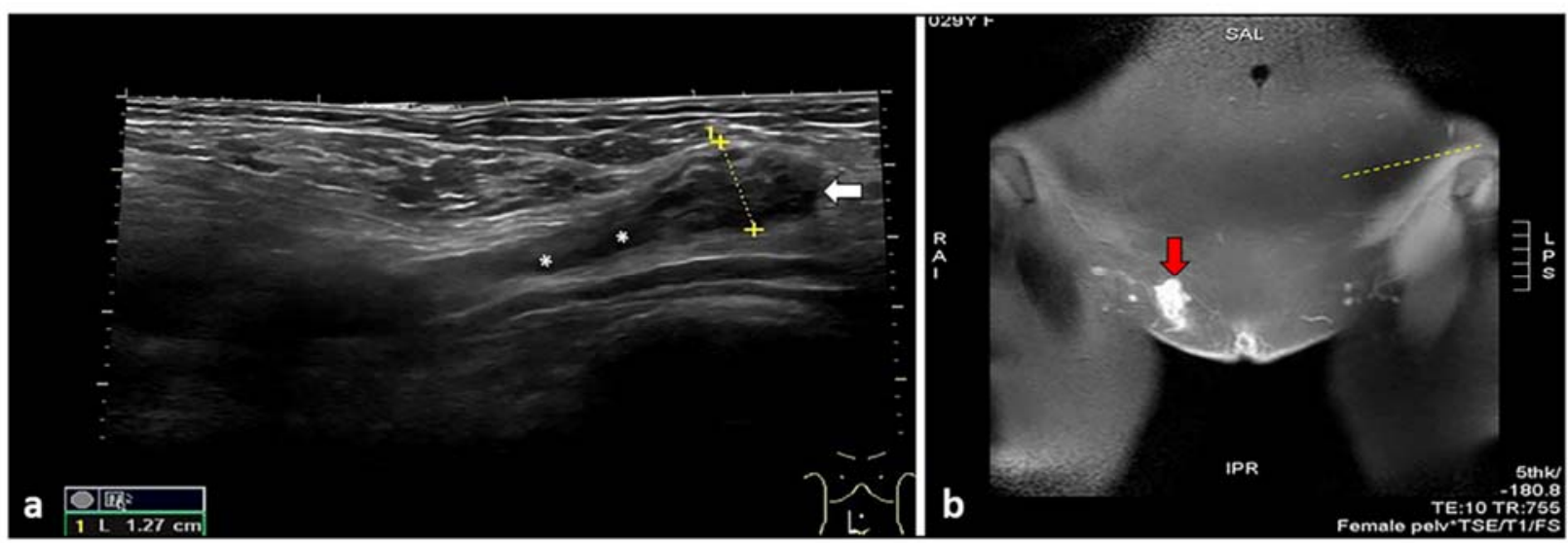

Figure 5. Extended field-of-view sonogram shows a hypoechoic and nodular mass (white arrow) located at the level of the Nuck canal (white asterisks) (a). Coronal T1-weighted MR image showing a hyperintense, pseudo-nodular mass (red arrow), confirming the presence of a hemorrhagic focus inside the inguinal canal representing endometriosis foci (b).

\section{Discussion}

AWE is limited to the peritoneal surface and is the result of previous gynecological surgery $[9,25,27,31,33]$. Caesarean section represents the strongest risk factor for AWE considering the close contact that may commonly occur between endometrial cells and the subcutaneous tissue during this type of surgery $[12,33]$. Despite the already high incidence 
of AWE of about $0.8 \%$ in all women with a previous caesarean section, it is certainly underestimated $[12,13]$. Early diagnosis of AWE is difficult because it is not always clinically detectable $[12,13]$. Several studies have found that the time interval between surgery and clinical presentation is 3 months to 10 years $[13,26,27]$. The pathophysiological processes underlying AWE remain unclear [34-38]. AWE is believed to be the result of mechanical iatrogenic implantation, through the direct inoculation of the abdominal fascia and/or subcutaneous tissue with endometrial cells during the surgical intervention. In this way, it becomes active and expands under estrogen stimulation [22]. Some authors have examined factors that contribute to Caesarean section endometriosis and have defined some possible causes, including: the easy separation and transport of endometrial cells by the flow of amniotic fluid into the pelvic cavity after hysterotomy; the large amount of endometrial cells spreading into the pelvis before hysterotomy closure, which can become trapped in the wound; and the nurturing role of blood and hormones after inoculation of the cells, allowing them to grow and develop in subcutaneous tissue [31]. It is important to highlight that a high incidence is reported after early hysterotomy (end of the second or beginning of the third trimester), as the early decidua seems to have more pluripotent capabilities, potentially resulting in enhanced cellular replication producing endometriosis [26-31,33]. AWE is often misdiagnosed with several other pathological conditions, such as hernias, hematomas, vascular anomalies desmoid tumors, lymphomas, metastatic carcinomas, Sister Mary Joseph nodules, and sarcomas [10,25,38-40]. Although an abdominal solid mass detected at ultrasound cannot be immediately considered to be endometriosis, if the lesion is located close to the surgical section, AWE should be suspected [13]. However, endometriosis guidelines indicate that only histological examination can provide definitive confirmation of the diagnosis [9]. AWE can have a single focus or multiple foci and the location can be variable and widespread; the qualitative assessment of pain often shows a close relationship with the menstrual cycle, and this represents the main clue for the diagnosis of endometriosis $[10,13,27]$. Malignant transformation has been reported in $1 \%$ of endometriosis cases and mainly involves ovarian endometriosis (approximately $80 \%$ ) [41,42]. There have been reports of malignant tumors occurring in AWE, although this transformation is quite rare and accounts for only $4.5 \%$ of all extra-genital neoplasms associated with endometriosis; in these cases, the most commonly reported histology is clear cell histology [41,42]. In a recent review, Ferrandina et al. described 23 cases of clear cell carcinoma resulting from Caesarean section endometriosis [43]. This cancer appears to be on the rise, probably due to greater knowledge of the disease and the increase in the rate of caesarean sections and uterine surgery in recent years $[13,43]$. The treatment of choice in all cases of abdominal wall endometriosis is a wide resection of the lesion, if necessary with partial resection of the underlying fascia. For most lesions, a margin of $1 \mathrm{~cm}$ is considered adequate [24].

B-mode ultrasound images with a convex multifrequency transducer $(2-8 \mathrm{MHz})$ can allow the identification of a non-specific nodule (often hypoechoic) with poor echostructural details (Figure 6); moreover, small endometriotic lesions sometimes cannot be detected. The high-multifrequency linear transducer (3-13 MHz; $4-15 \mathrm{MHz} ; 8-24 \mathrm{MHz}$ ) can provide precise details for the surgeon, such as better definition of echostructural features and depths of the endometriotic lesion from the cutaneous plane. The endometriotic nodule may appear solid with variable echogenicity, usually hypoechoic or partially cystic (hypoanechoic) with ill-defined margins or speculated borders; intralesional vascular spots are often depicted with color-power Doppler (Figure 7a-c) [13,43]. 


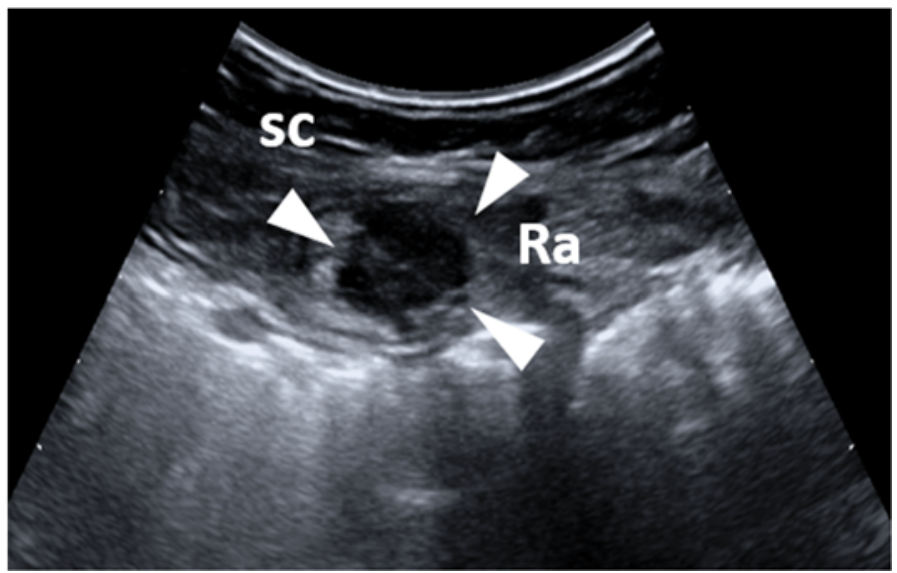

Figure 6. Short-axis sonogram with a convex transducer shows a hypoechoic, nodular mass (white arrow), located on the peritoneal superface, and inside the rectus abdominis (Ra) muscle. sc: subcutaneous tissue.
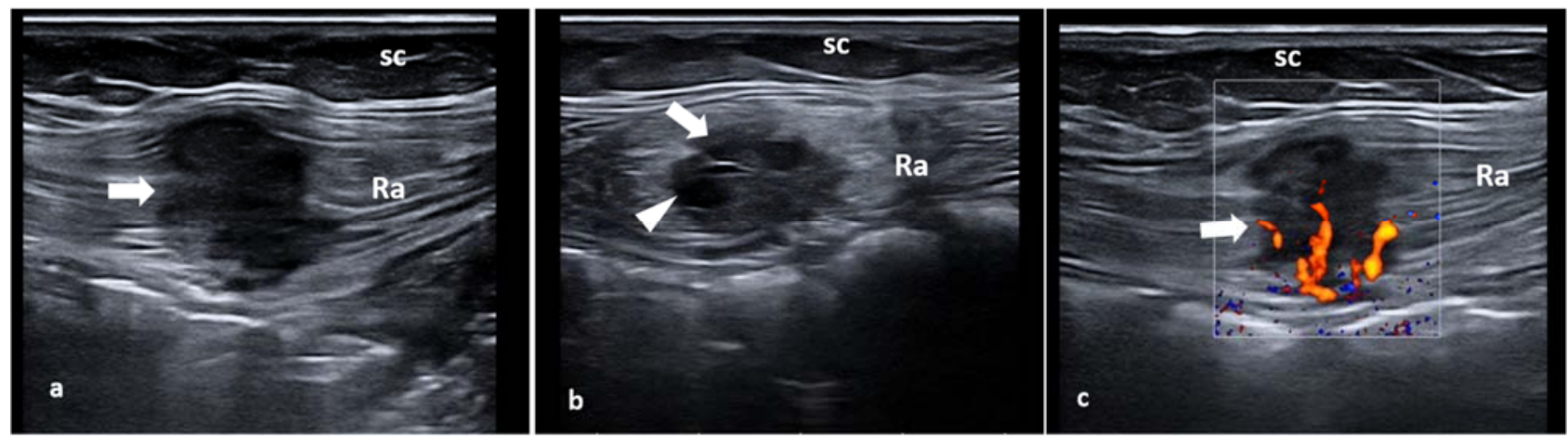

Figure 7. Long-axis sonograms show a hypoechoic, nodular mass inside the rectus abdominis with speculated borders (a). Short-axis sonograms show a partially cystic nodular (hypo-anechoic) mass with ill-defined margins (b). Fine intralesional vascular spots are depicted with color-power Doppler (c). sc: subcutaneous tissue ra: rectus abdominis muscle.

Strain and share wave elastography may improve the characterization of lesions by highlighting the fibrotic component in endometriotic tissue. Indeed, several cell types, including activated platelets, macrophages, ectopic endometrial cells, and sensory nerve fibers, contribute to the development of fibrosis [44,45]. Elastography may be particularly useful if the lesion is isoechoic with respect to the surrounding tissue. In fact, strain and share wave elastography can detect a different stiffness pattern of endometrial lesion with respect to the surrounding tissue, thus confirming the ectopic nature of the masses (Figures 8 and 9) [27]. Magnetic resonance is the method of choice to accurately define the involvement of different anatomical structures and diagnose the presence of deep endometriosis $[46,47]$. 


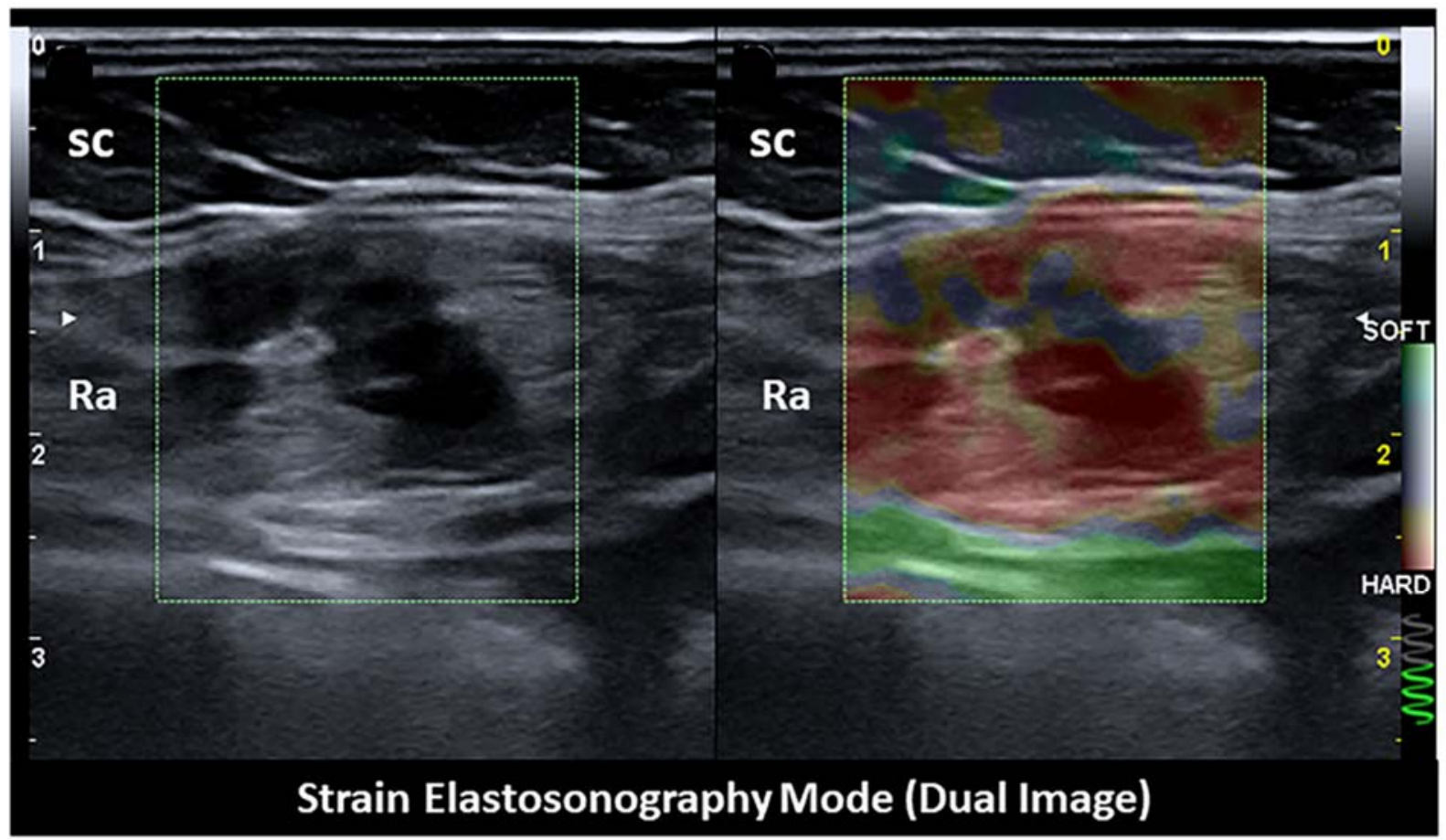

Figure 8. Strain elastosonography mode revealing the hard pattern of the endometriotic nodule. sc: subcutaneous tissue. ra: rectus abdominis muscle.
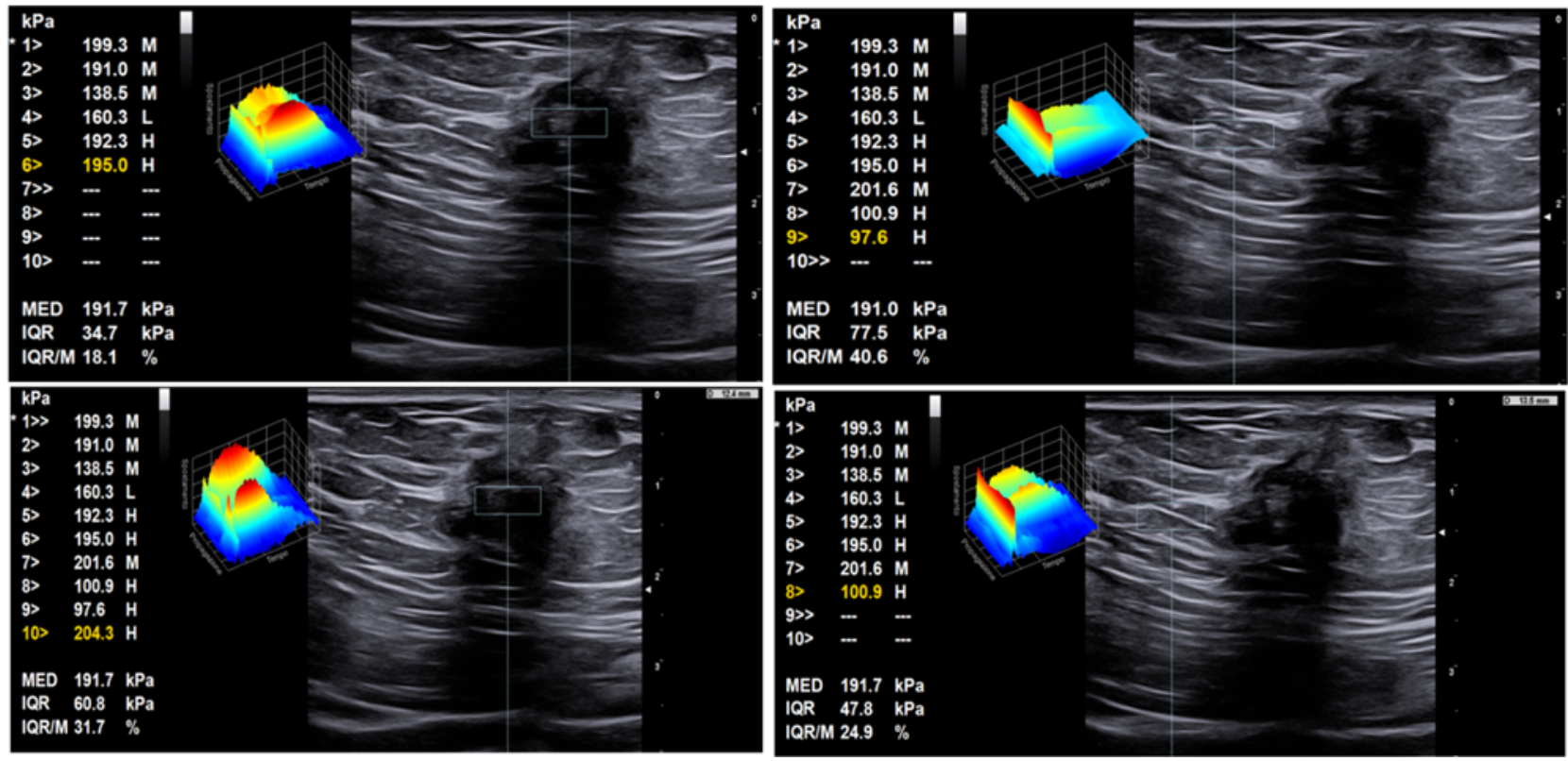

Figure 9. Share wave elastosonography mode revealing the hard pattern of the endometriotic nodule with respect to the surrounding tissue. Left: ROI within the tumor, with high shear wave pressures between 195 and 204 kPa; right: ROI within soft tissue surrounding the tumor, with distinctly lower shear wave pressures of 98-101 kPa.

\section{Therapeutic Options}

Surgical excision is the treatment of choice in AWE. A wide incision for endometriotic nodules is recommended due to the risk of recurrence in $5-9 \%$ of cases $[48,49]$. For most lesions, a margin of $1 \mathrm{~cm}$ is considered adequate [24].

In select cases (e.g., in patients having high surgical risk or refusing surgical intervention) minimally invasive or conservative treatments can be proposed: sclerotherapy, 
high-intensity focused ultrasound ablation (HIFUA), or cryoablation and combined oral contraceptives [48]. Sclerotherapy with ultrasound guided ethanol injection into the scar endometriosis has been reported to be effective in some cases [50]. Recently, some authors have suggested HIFUA, but data are still scarce [51-53]. Crioablation has an emerging role in select patients with AWE [54]. Recently, case reports and small case series have described successful US or CT guided thermal ablation of AWE with durable symptomatic relief $[55,56]$. This technique is performed with argon-based cryoablation systems using cryoprobes [54]. Although from few studies, a clinical improvement with conservative treatment combining oral contraceptive progestogen and hormone suppression therapy with gonadotropin-releasing hormone $(\mathrm{GnRH})$ analogues was also reported [48].

\section{Conclusions}

AWE following obstetric and gynecological surgery is becoming more frequently diagnosed due to the increasing number of cesarean sections worldwide. AWE should be suspected in any woman of childbearing age with a lump in the incisional scar area after pelvic surgery and pain that is strongly correlated to her menstrual cycle. AWE may be difficult to diagnose, especially if the mass is not palpable. Ultrasound imaging by a high multifrequency linear transducer is a precious tool to identify and characterize endometriotic lesions in the superficial tissues of the abdominal wall.

Author Contributions: Conceptualization, G.C.; methodology, G.C. and A.D.P.; software, A.B.; validation, G.B., M.R., M.C. and C.S.; formal analysis, A.B. and V.R.; investigation, G.C. and M.T.; resources, G.C. and A.D.P.; data curation, G.C. and A.B.; writing-original draft preparation, G.C.; writing-review and editing, G.C. and A.D.P. visualization, A.D.P. and M.S.; supervision, C.S.; project administration, G.C. and C.S.; funding acquisition, C.S. All authors have read and agreed to the published version of the manuscript.

Funding: This research received no external funding.

Informed Consent Statement: Informed consent was obtained from all subjects involved in the study.

Conflicts of Interest: The authors declare no conflict of interest.

\section{References}

1. Parazzini, F.; Esposito, G.; Tozzi, L.; Noli, S.; Bianchi, S. Epidemiology of endometriosis and its comorbidities. Eur. J. Obstet. Gynecol. Reprod. Biol. 2017, 209, 3-7. [CrossRef]

2. Rokitansky, K. Über Uterusdrüsen-Neubildung. Z. Ges. Aerzte 1860, 16, 577-581.

3. Missmer, S.A.; Tu, F.F.; Agarwal, S.K.; Chapron, C.; Soliman, A.M.; Chiuve, S.; Eichner, S.; Flores-Caldera, I.; Horne, A.W.; Kimball, A.B.; et al. Impact of Endometriosis on Life-Course Potential: A Narrative Review. Int. J. Gen. Med. 2021, 14, 9-25. [CrossRef] [PubMed]

4. Chapron, C.; Marcellin, L.; Borghese, B.; Santulli, P. Rethinking mechanisms, diagnosis and management of endometriosis. Nat. Rev. Endocrinol. 2019, 15, 666-682. [CrossRef] [PubMed]

5. Simoens, S.; Dunselman, G.; Dirksen, C.; Hummelshoj, L.; Bokor, A.; Brandes, I.; Brodszky, V.; Canis, M.; Colombo, G.L.; De Leire, T.; et al. The burden of endometriosis: Costs and quality of life of women with endometriosis and treated in referral centres. Hum. Reprod. 2012, 27, 1292-1299. [CrossRef] [PubMed]

6. Nnoaham, K.E.; Hummelshoj, L.; Webster, P.; d’Hooghe, T.; de Cicco Nardone, F.; de Cicco Nardone, C.; Jenkinson, C.; Kennedy, S.H.; Zondervan, K.T.; World Endometriosis Research Foundation Global Study of Women's Health Consortium. Impact of endometriosis on quality of life and work productivity: A multicenter study across ten countries. Fertil. Steril. 2011, 96, 366-373.e8. [CrossRef]

7. Scioscia, M.; Bruni, F.; Ceccaroni, M.; Steinkasserer, M.; Stepniewska, A.; Minelli, L. Distribution of endometriotic lesions in endometriosis stage IV supports the menstrual reflux theory and requires specific preoperative assessment and therapy. Acta Obs. Gynecol. Scand. 2011, 90, 136-139. [CrossRef] [PubMed]

8. Davis, A.C.; Goldberg, J.M. Extrapelvic endometriosis. Semin. Reprod. Med. 2017, 35, 98-101.

9. Hirsch, M.; Begum, M.R.; Paniz, É.; Barker, C.; Davis, C.J.; Duffy, J.M.N. Diagnosis and management of endometriosis: A systematic review of international and national guidelines. BJOG 2018, 125, 556-564. [CrossRef]

10. Savelli, L.; Manuzzi, L.; Di Donato, N.; Salfi, N.; Trivella, G.; Ceccaroni, M.; Seracchioli, R. Endometriosis of the abdominal wall: Ultrasonographic and Doppler characteristics. Ultrasound Obstet. Gynecol. 2012, 39, 336-340. [CrossRef]

11. Betrán, A.P.; Ye, J.; Moller, A.-B.; Zhang, J.; Gülmezoglu, A.M.; Torloni, M.R. The increasing trend in caesarean section rates: Global, regional and national estimates: 1990-2014. PLOS ONE 2016, 11, e0148343. 
12. Rindos, N.B.; Mansuria, S. Diagnosis and Management of Abdominal Wall Endometriosis: A Systematic Review and Clinical Recommendations. Obstet Gynecol Surv. 2017, 72, 116-122. [CrossRef]

13. Nominato, N.S.; Prates, L.F.V.S.; Lauar, I.; Morais, J.; Maia, L.; Geber, S. Caesarean section greatly increases risk of scar endometriosis. Eur. J. Obstet. Gynecol. Reprod. Biol. 2010, 152, 83-85. [CrossRef] [PubMed]

14. Haak, H.E.; Maas, M.; Lahaye, M.J.; Boellaard, T.N.; Pizzi, A.D.; Mihl, C.; Van Der Zee, D.; Fabris, C.; Van Der Sande, M.E.; Melenhorst, J.; et al. Selection of Patients for Organ Preservation After Chemoradiotherapy: MRI Identifies Poor Responders Who Can Go Straight to Surgery. Ann. Surg. Oncol. 2020, 27, 2732-2739. [CrossRef] [PubMed]

15. Pizzi, A.D.; Caposiena, D.; Mastrodicasa, D.; Trebeschi, S.; Lambregts, D.; Rosa, C.; Cianci, R.; Seccia, B.; Sessa, B.; Di Flamminio, F.M.; et al. Tumor detectability and conspicuity comparison of standard b1000 and ultrahigh b2000 diffusionweighted imaging in rectal cancer. Abdom. Radiol. 2019, 44, 3595-3605. [CrossRef] [PubMed]

16. Pizzi, A.D.; Tavoletta, A.; Narciso, R.; Mastrodicasa, D.; Trebeschi, S.; Celentano, C.; Mastracchio, J.; Cianci, R.; Seccia, B.; Marrone, L.; et al. Prenatal planning of placenta previa: Diagnostic accuracy of a novel MRI-based prediction model for placenta accreta spectrum (PAS) and clinical outcome. Abdom. Radiol. 2019, 44, 1873-1882. [CrossRef] [PubMed]

17. Alnafisah, F.; Dawa, S.K.; Alalfy, S. Skin endometriosis at the caesarean section scar: A case report and review of the literature. Cureus 2018, 10, e2063. [CrossRef] [PubMed]

18. Raffi, L.; Suresh, R.; McCalmont, T.H.; Twigg, A.R. Cutaneous endometriosis. Int. J. Womens Derm. 2019, 5, 384-386. [CrossRef]

19. Ismael, H.; Ragoza, Y.; Harden, A.; Cox, S. Spontaneous endometriosis associated with an umbilical hernia: A case report and review of the literature. Int. J. Surg. Case Rep. 2017, 30, 1-5. [CrossRef] [PubMed]

20. Victory, R.; Diamond, M.P.; Johns, D.A. Villar's nodule: A case report and systematic literature review of endometriosis externa of the umbilicus. J. Minim. Invasive Gynecol. 2007, 14, 23-32. [CrossRef] [PubMed]

21. Mann, L.S.; Clarke, W.R. Endometriosis of the umbilicus. IMJ III Med. J. 1964, 125, 335-336.

22. Wicherek, L.; Klimek, M.; Skret-Magierlo, J.; Czekierdowski, A.; Banas, T.; Popiela, T.J.; Kraczkowski, J.; Sikora, J.; Oplawski, M.; Nowak, A.; et al. The obstetrical history in patients with Pfannenstiel scar. Gynecol. Obstet. Investig. 2007, 63, 107-113. [CrossRef]

23. Bagade, P.V.; Guirguis, M.M. Menstruating from the umbilicus as a rare case of primary umbilical endometriosis: A case report. J. Med. Case Rep. 2009, 3, 9326. [CrossRef]

24. Paramythiotis, D.; Stavrou, G.; Panidis, S.; Panagiotou, D.; Chatzopoulos, K.; Papadopoulos, V.N.; Michalopoulos, A. Concurrent appendiceal and umbilical endometriosis: A case report and review of the literature. J. Med. Case Rep. 2014, 8, 258. [CrossRef] [PubMed]

25. Draghi, F.; Cocco, G.; Richelmi, F.M.; Schiavone, C. Abdominal wall sonography: A pictorial review. J. Ultrasound 2020, 23, 265-278. [CrossRef] [PubMed]

26. Zhang, P.; Sun, Y.; Zhang, C.; Yang, Y.; Zhang, L.; Wang, N.; Xu, H. Cesarean scar endometriosis: Presentation of 198 cases and literature review. BMC Womens Health 2019, 19, 14. [CrossRef]

27. Cocco, G.; Ricci, V.; Boccatonda, A.; Schiavone, C. Focused ultrasound for the diagnosis of non-palpable endometriotic lesions of the abdominal wall: A not-uncommon surgical complication. J. Ultrasound 2020, 23, 183-187. [CrossRef] [PubMed]

28. Okoshi, K.; Mizumoto, M.; Kinoshita, K. Endometriosis-associated hydrocele of the canal of Nuck with immunohistochemical confirmation: A case report. J. Med. Case Rep. 2017, 11, 354. [CrossRef] [PubMed]

29. Block, R.E. Hydrocele of the canal of Nuck. A report of five cases. Obstet. Gynecol. 1975, 45, 464-466.

30. Jimenez, M.; Miles, R.M. Inguinal endometriosis. Ann. Surg. 1960, 151, 903-911. [CrossRef]

31. Hufnagel, D.; Li, F.; Cosar, E.; Krikun, G.; Taylor, H.S. The role of stem cells in the etiology and pathophysiology of endometriosis. Semin. Reprod. Med. 2015, 33, 333-340. [CrossRef] [PubMed]

32. Prodromidou, A.; Pandraklakis, A.; Rodolakis, A.; Thomakos, N. Endometriosis of the Canal of Nuck: A Systematic Review of the Literature. Diagnostics 2020, 11, 3. [CrossRef] [PubMed]

33. Scioscia, M.; Pesci, A.; Scardapane, A.; Noventa, M.; Bonaccorsi, G.; Greco, P.; Zamboni, G. Dye diffusion during laparoscopic tubal patency tests may suggest a lymphatic contribution to dissemination in endometriosis: A prospective, observational study. PLoS ONE 2019, 14, e0226264. [CrossRef] [PubMed]

34. Zhao, Y.; Zhang, J.; Zamora, J.; Vogel, J.P.; Souza, J.P.; Jayaratne, K.; Ganchimeg, T.; Ortiz-Panozo, E.; Hernandez, B.; Oladapo, O.T.; et al. Increases in caesarean delivery rates and change of perinatal outcomes in low- and middle-income countries: A hospital-level analysis of two WHO surveys. Paediatr. Perinat. Epidemiol. 2017, 31, 251-262. [CrossRef]

35. Burney, R.O.; Giudice, L.C. Pathogenesis and pathophysiology of endometriosis. Fertil. Steril. 2012, 98, 511-519. [CrossRef] [PubMed]

36. Wang, P.-H.; Juang, C.-M.; Chao, H.-T.; Yu, K.-J.; Yuan, C.-C.; Ng, H.-T. Wound endometriosis: Risk factor evaluation and treatment. J. Chin. Med. Assoc. 2003, 66, 113-119. [PubMed]

37. Oosterlynck, D.J.; Cornillie, F.J.; Waer, M.; Vandeputte, M.; Koninckx, P.R. Women with endometriosis show a defect in natural killer activity resulting in a decreased cytotoxicity to autologous endometrium. Fertil. Steril. 1991, 56, 45-51. [CrossRef]

38. Cocco, G.; Ricci, V.; Boccatonda, A.; Stellin, L.; de Filippis, G.; Soresi, M.; Schiavone, C. Sonographic demonstration of a spontaneous rectus sheath hematoma following a sneeze: A case report and review of the literature. J. Ultrasound 2020. [CrossRef] [PubMed]

39. Cocco, G.; Ricci, V.; Cocco, N.; Boccatonda, A.; D'Ardes, D.; Basilico, R.; Schiavone, C. Sonography of abdominal wall vascular malformation: A case report and review of the literature. J. Ultrasound 2020, 23, 481-485. [CrossRef] 
40. Cocco, G.; Boccatonda, A.; D'Ardes, D.; Galletti, S.; Schiavone, C. Mantle cell lymphoma: From ultrasound examination to histological diagnosis. J. Ultrasound 2018, 21, 339-342. [CrossRef]

41. Fàbregas, F.F.; Guimferrer, M.C.; Casas, F.T.; Caballero, S.B.; Xauradó, R.F. Malignant transformation of abdominal wall endometriosis with lymph node metastasis: Case report and review of literature. Gynecol. Oncol. Case Rep. 2014, 8, 10-13. [CrossRef]

42. Graur, F.; Mois, E.; Elisei, R.; Furcea, L.; Dragota, M.; Zaharie, T.; Al Hajjar, N. Malignant endometriosis of the abdominal wall. Ann. Ital. Chir. 2017, 6, S2239253X17026895.

43. Ferrandina, G.; Palluzzi, E.; Fanfani, F.; Gentileschi, S.; Valentini, A.L.; Mattoli, M.V.; Pennacchia, I.; Scambia, G.; Zannoni, G. Endometriosis-associated clear cell carcinoma arising in caesarean section scar: A case report and review of the literature. World J. Surg. Oncol. 2016, 14, 300. [CrossRef] [PubMed]

44. Xie, M.; Zhang, X.; Zhan, J.; Ren, Y.; Wang, W. Potential role of strain elastography for detection of the extent of large-scar endometriosis. J. Ultrasound Med. 2013, 32, 1635-1642. [CrossRef]

45. Viganò, P.; Ottolina, J.; Bartiromo, L.; Bonavina, G.; Schimberni, M.; Villanacci, R.; Candiani, M. Cellular Components Contributing to Fibrosis in Endometriosis: A Literature Review. J. Minim. Invasive Gynecol. 2020, 27, 287-295. [CrossRef]

46. Guerriero, S.; Saba, L.; Pascual, M.A.; Ajossa, S.; Rodriguez, I.; Mais, V.; Alcazar, J.L. Transvaginal ultrasound vs magnetic resonance imaging for diagnosing deep infiltrating endometriosis: Systematic review and meta-analysis. Ultrasound Obstet. Gynecol. 2018, 51, 586-595. [CrossRef] [PubMed]

47. Scioscia, M.; Orlandi, S.; Trivella, G.; Portuese, A.; Bettocchi, S.; Pontrelli, G.; Bocus, P.; Anna Virgilio, B. Sonographic Differential Diagnosis in Deep Infiltrating Endometriosis: The Bowel. BioMed Res. Int. 2019, 2019, 5958402. [CrossRef]

48. Carsote, M.; Terzea, D.C.; Valea, A.; Gheorghisan-Galateanu, A.A. Abdominal wall endometriosis (a narrative review). Int. J. Med. Sci. 2020, 17, 536-542. [CrossRef]

49. Lopez-Soto, A.; Sanchez-Zapata, M.I.; Martinez-Cendan, J.P.; Ortiz Reina, S.; Bernal Mañas, C.M.; Remezal Solano, M. Cutaneous endometriosis: Presentation of 33 cases and literature review. Eur. J. Obs. Gynecol. Reprod. Biol. 2018, 221, 58-63. [CrossRef]

50. Bozkurt, M.; Çil, A.S.; Bozkurt, D.K. Intramuscular abdominal wall endometriosis treated by ultrasound-guided ethanol injection. Clin. Med. Res. 2014, 12, 160-165. [CrossRef]

51. Xiao-Ying, Z.; Hua, D.; Jin-Juan, W.; Ying-Shu, G.; Jiu-Mei, C.; Hong, Y.; Chun-Yi, Z. Clinical analysis of high-intensity focussed ultrasound ablation for abdominal wall endometriosis: A 4-year experience at a specialty gynecological institution. Int. J. Hyperth. 2019, 36, 87-94. [CrossRef] [PubMed]

52. Zhao, L.; Deng, Y.; Wei, Q.; Chen, J.; Zhao, C. Comparison of ultrasound-guided high-intensity focused ultrasound ablation and surgery for abdominal wall endometriosis. Int. J. Hyperth. 2018, 35, 528-533. [CrossRef] [PubMed]

53. Lee, J.-S.; Kim, Y.-J.; Hong, G.-Y.; Nam, S.-K.; Kim, T.-E. Abdominal wall endometriosis treatment by ultrasound-guided high-intensity focused ultrasound ablation: A case report. Gynecol. Endocrinol. 2019, 35, 109-111. [CrossRef]

54. Welch, B.T.; Ehman, E.C.; Van Buren, W.M.; Cope, A.G.; Welch, T.L.; A Woodrum, D.; Kurup, A.N.; Burnett, T.L. Percutaneous cryoablation of abdominal wall endometriosis: The Mayo Clinic approach. Abdom. Radiol. 2020, 45, 1813-1817. [CrossRef] [PubMed]

55. Dibble, E.H.; D’Amico, K.C.; Bandera, C.A.; Littrup, P.J. Cryoablation of Abdominal Wall Endometriosis: A Minimally Invasive Treatment. AJR Am. J. Roentgenol. 2017, 209, 690-696. [CrossRef]

56. Maillot, J.; Brun, J.L.; Dubuisson, V.; Bazot, M.; Grenier, N.; Cornelis, F.H. Mid-term outcomes after percutaneous cryoablation of symptomatic abdominal wall endometriosis: Comparison with surgery alone in a single institution. Eur. Radiol. 2017, 27, 4298-4306. [CrossRef] 